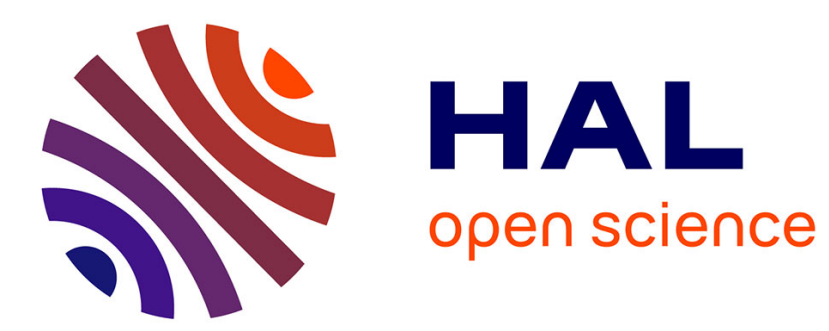

\title{
Solar radiation climate in Africa
}

Lamissa Diabate, Philippe Blanc, Lucien Wald

\section{To cite this version:}

Lamissa Diabate, Philippe Blanc, Lucien Wald. Solar radiation climate in Africa. Solar Energy, 2004, 76, pp.733-744. hal-00361362

\section{HAL Id: hal-00361362 https://hal.science/hal-00361362}

Submitted on 13 Feb 2009

HAL is a multi-disciplinary open access archive for the deposit and dissemination of scientific research documents, whether they are published or not. The documents may come from teaching and research institutions in France or abroad, or from public or private research centers.
L'archive ouverte pluridisciplinaire HAL, est destinée au dépôt et à la diffusion de documents scientifiques de niveau recherche, publiés ou non, émanant des établissements d'enseignement et de recherche français ou étrangers, des laboratoires publics ou privés. 


\title{
SOLAR RADIATION CLIMATE IN AFRICA
}

\author{
Diabaté L. (1), Blanc Ph. (2), Wald L. (3)*
}

(1) UFAE / GCMI, BP E4018, 410, avenue Van Vollenhoven, Bamako, Mali

(2) Alcatel Space, BP 99, Cannes, France

(3)* Corresponding author. Groupe Télédétection \& Modélisation, Ecole des Mines de Paris, BP 207, 06904 Sophia Antipolis cedex, France. Tel.: +33 (0) 4.93.95.74.49 - Fax: +33 (0) 4.93.95.75.35. E-mail: lucien.wald@ensmp.fr

\section{$\underline{\text { ABSTRACT }}$}

This work is a first attempt to propose a map of the solar radiation climate in Africa. Such a map is very useful for preliminary assessment and modeling of solar energy systems. Following the approach adopted for Europe, a data set of monthly means of the daily clearness index has been assembled for 62 sites. A cluster analysis was applied to create 20 classes that were reported on a map of Africa. These classes were geographically extended, thus creating a solar radiation climate map, comprising 20 climates. Known features and other atlases, global or local, were used in this mapping. This map and its companion tables permit to perform elementary energy calculations. Further improvements are discussed.

Keywords: clearness index, atmosphere optics, clustering, interpolation, map, solar energy systems

Nomenclature:

$\left(K T_{\mathrm{d}}\right)_{\mathrm{m}}$ : monthly mean daily clearness index

$\left(G_{\mathrm{d}}\right)_{\mathrm{m}}$ : monthly mean daily global irradiation $\left(\mathrm{J} / \mathrm{m}^{2}\right)$

$\left(G_{0 \mathrm{~d}}\right)_{\mathrm{m}}:$ monthly mean daily extraterrestrial global irradiation $\left(\mathrm{J} / \mathrm{m}^{2}\right)$

$\Phi_{P}, \Phi_{X}$ : latitude of a point $\boldsymbol{P}$, of a point $\boldsymbol{X}$ (decimal degrees)

$d_{\text {geo }}$ : geodetic distance $(\mathrm{km})$

$d_{\text {eff: }}$ effective distance $(\mathrm{km})$

$f_{N S}$ : a unitless parameter for interpolation taking into account the latitudinal asymmetry of the climate phenomena $\delta$ : difference in elevation between the point $\boldsymbol{P}$ and another site $\boldsymbol{X}(\mathrm{km})$ $f_{\text {oro }}$ : a unitless parameter for interpolation taking into account the difference in elevation $(=500)$ 


\section{Introduction}

Knowing the solar climate in Africa is a challenge. Only few measuring sites are available with long-term timeseries of accurate measurements. For such a site, the time structure may be derived that characterizes the solar climate. The monthly mean of the daily clearness index $\left(K T_{\mathrm{d}}\right)_{\mathrm{m}}$ is an appropriate variable in that respect. It is defined by the ratio of the monthly mean daily global irradiation $\left(G_{\mathrm{d}}\right)_{\mathrm{m}}$ and the monthly mean daily extraterrestrial irradiation $\left(G_{0 \mathrm{~d}}\right)_{\mathrm{m}}$, following the notations of the European solar radiation atlas (ESRA 2000):

$\left(\mathrm{KT}_{\mathrm{d}}\right)_{\mathrm{m}}=\left(\mathrm{G}_{\mathrm{d}}\right)_{\mathrm{m}} /\left(\mathrm{G}_{0 \mathrm{~d}}\right)_{\mathrm{m}}$

A typical value of $\left(\mathrm{KT}_{\mathrm{d}}\right)_{\mathrm{m}}$ for Paris, France, is 0.4 (ESRA 2000). That means that $40 \%$ of the extraterrestrial irradiation reaches the ground.

$\left(\mathrm{KT}_{\mathrm{d}}\right)_{\mathrm{m}}$ is a dimensionless quantity. Its use helps suppress variations due monthly mean to variations in extraterrestrial irradiation, which are also strongly dependent on latitude. This index brings out with greater clarity global radiation variations due to climate impacts, i.e. site altitude, site cloudiness and atmospheric turbidity.

The difficulty in solar climate lies in the comprehension of the spatial dimension. Due to the scarcity of the network, the boundaries of a climatic area are difficult to draw. However, zoning helps in a better understanding of the distribution of the clearness index in space. It also guides the selection of appropriate measuring stations for a given geographical location. Incidentally, it also helps with the Ångström coefficients by defining the geographical limits of the validity of a given set of coefficients.

Such a zoning effort was recently performed for Europe and has been published under the form of maps (ESRA 2000). The present paper reports on a similar effort made for Africa, though the resources spent and the number of stations used are limitations to the analogy.

Solar radiation climatic zoning is of large importance for preliminary assessment and modeling of systems using solar radiation, whether they are natural systems, e.g., vegetation and fauna (Thompson, Perry 1997), or energy conversion artificial system, e.g., photovoltaics. Some atlases of solar irradiation are available for Africa (Ba et al. 2001; Bahraoui-Buret et al. 1983; Raschke et al. 1991). They are either limited to a country or are made of isolines or colored maps at large scale (1 degree or so). Values are difficult to handle and these atlases are not offering such a zoning for the whole Africa. The maps provided by the World Meteorological Organization (WMO 1981) are covering the whole world but exhibit very limited spatial details. That is why an effort was made to produce a map of solar radiation climate in Africa, benefiting from these atlases and other available 
information. As for the ESRA and Dogniaux, Lemoine (1983), the present study uses the monthly mean of the daily clearness index $\left(K T_{\mathrm{d}}\right)_{\mathrm{m}}$ as a basic quantity to define the zoning.

\section{Data}

The WMO published a CD-ROM containing global climate normals (CLINO) for the period 1961-1990 (WMO 1998). This CLINO database would have been a good source of data; unfortunately, it does not contain solar irradiation values for Africa. The possibility to use sunshine duration observations was examined. There are approximately 400 stations measuring the sunshine duration in the CLINO. However, there were two obstacles. Firstly, the spatial distribution is very heterogeneous. There is no information for large portions of Africa (Fig. 1). Secondly, the conversion of sunshine duration into global irradiation and clearness index through the Ångström relationship is not obvious and spatially dependent. Coincident time-series of sunshine duration and clearness index are necessary to derive such a relationship, whose coefficients are valid only locally.

Time-series were available at the Web site of the World Radiation Data Center (WRDC). Thirty-six stations: seventeen sites in Morocco, nine in Egypt, two in Mozambique, Zambia and Zimbabwe, and one for Algeria, Ghana, Tunisia and Western Sahara, were found, having time-series of daily sums of global radiation (daily irradiation) spanning several years (Table 1). At the time of data collection, it was only possible to display the data on the computer screen when accessing Web site of the WRDC with no possibility of downloading data; the data were then manually digitized at the UFAE with possible typing errors. The data span the period 1994-1998, that is 5 years, except for Mersa Matruh, Egypt, where the period is 1995-1998 (4 years) and Tamanrasset, Algeria, with a period 1995-1999 (5 years). The quality of these measurements was controlled by the means of the Web tool described by Geiger et al. (2003). It performs a likelihood control of the data and checks the plausibility of the measurements. Once, the questionable data removed, monthly means of daily irradiation were computed by averaging the data for a same month and all years. The results are a series of twelve values (one per month) for each site.

The retained stations do not cover the whole Africa. Information was added in uncovered areas by using existing atlases. The solar radiation atlas of Africa by Raschke et al. (1991) was established by means of Meteosat data. It covers the period 1985-1986 and offers a relative accuracy of 15 - 20\% in monthly means of daily irradiation. This atlas exists only in paper format. The process of reading colored maps and converting them into figures is inaccurate and very tedious. Nevertheless, it was the only means known to the authors for getting information in large uncovered areas. Eighteen sites were added in that way, especially between tropics, where data are scarce. 
When possible, the values were checked for consistency with the maps shown in Ba et al. (2001) for January, April, July and October. In Table 1, the names of these sites comprise the word "Sunsat".

For Northern Africa, we used the ESRA (2000). This atlas covers the period 1981-1990. Digital values of monthly means of daily irradiation can be read on the screen for any site with a relative accuracy of 5-10\% (Beyer et al. 1997). Eight sites were added in that way for areas North of the parallel $25^{\circ}$ N. Their names comprise the word "ESRA".

We thus obtain a total of 62 sites. The periods under concern are different. Beyer et al. (1997) or Ba et al. (2001) report that inter-annual changes are of order of up to $10 \%$ in relative value. The effect of using different periods is reduced by averaging over several years but not eliminated. This effect is smaller than the accuracy of the assessment mentioned by the ESRA or Raschke et al. The series of monthly means of daily irradiation were then converted into clearness index $\left(\mathrm{KT}_{\mathrm{d}}\right)_{\mathrm{m}}$ by dividing by the monthly mean of the daily sum of the extraterrestrial irradiance $\left(G_{0 \mathrm{~d}}\right)_{\mathrm{m}} \cdot\left(\mathrm{KT}_{\mathrm{d}}\right)_{\mathrm{m}}$ is given in Table 2 for each month and each site.

\section{Clustering and processing procedures}

As for the ESRA, the method selected for the creation of the climatic zones is a cluster analysis. It arranges the 62 stations in classes or clusters. The procedure aims at forming classes such that items of a given class are as similar as possible, while they are as different as possible from items of other classes. Because it makes no sense to perform a cluster analysis with correlated variables, a correlation matrix was calculated on the time-series of $\left(\mathrm{KT}_{\mathrm{d}}\right)_{\mathrm{m}}$. The results showed that the variables were not correlated with each other. The similarity between two stations can be computed by the means of the Euclidean distance computed on the two vectors of $\left(\mathrm{KT}_{\mathrm{d}}\right)_{\mathrm{m}}$. This distance is the sum over the twelve months of the square of the differences between each pair of $\left(\mathrm{KT}_{\mathrm{d}}\right)_{\mathrm{m}}$. The more similar the $\left(\mathrm{KT}_{\mathrm{d}}\right)_{\mathrm{m}}$, the smaller the difference. This distance is computed for each possible pair of stations.

Then, a hierarchical cluster tree is created by applying the algorithm of Ward (1963). The linkage between two objects is based upon their proximity in the space of $\left(\mathrm{KT}_{\mathrm{d}}\right)_{\mathrm{m}}$. The closest stations are first aggregated and produce a new object (or cluster) whose properties, i.e. time-series of $\left(\mathrm{KT}_{\mathrm{d}}\right)_{\mathrm{m}}$, are an average of the individual $\left(\mathrm{KT}_{\mathrm{d}}\right)_{\mathrm{m}}$ for each month. The distances between this cluster and all other stations are re-computed. Using also the set of distances computed before, the process is iterated to construct a hierarchical cluster tree, until there is a unique cluster. An important parameter is the overall heterogeneity within the clusters as a function of the number of clusters. This function is a weighted sum of the distances within a cluster and is similar to an intra-cluster variance (Fig. 2). It reaches its minimum when no merging is made, that is when the number of clusters (or classes) is equal to the 
number of stations. It is maximum when the number of cluster is 1 . It increases slowly as the merging proceeds, and the number of clusters decreases. If a sharp increase at a given number of clusters is observed, it indicates the forming of a heterogeneous cluster from two homogeneous clusters and indicates the end of the process of merging. This critical number is the final number of clusters. In this case, no sharp increase is found. We have to find a tradeoff for having a number of classes large enough to describe the climate and aggregated enough to represent a step forward the use of individual stations. One may note in Fig. 2 that there is no variation of the intra-cluster variance for a number of classes between 20 and 24 . That means that several classes are very similar and that there is no loss of information by aggregating them. Hence, it seems that a number of 20 clusters is appropriate to describe the timeseries of $\left(\mathrm{KT}_{\mathrm{d}}\right)_{\mathrm{m}}$. Table 3 lists the stations contained in each cluster.

The cluster to which a station belongs is reported on a map of Africa for the geographical coordinates of the station. An initial map of the solar radiation climate is created by geographically extending these classes by spatial interpolation by the means of the nearest-neighbor technique. The distance used here is that described by Lefèvre et al. (2002a) who found an increase in accuracy by adding latitudinal and orographic effects to the geodetic distance. Assuming that the cluster value should be assessed at a given geographical point $\boldsymbol{P}$, this effective distance $d_{\text {eff }}$ is as follows:

$d_{\text {eff }}^{2}=f_{N S}^{2}\left(d_{\text {geo }}^{2}+f_{\text {oro }}^{2} \delta h^{2}\right)$

with $f_{N S}=1+0.3 / \Phi_{P}-\Phi_{X} /\left[1+\left(\sin \Phi_{P}+\sin \Phi_{X}\right) / 2\right]$, where $d_{g e o}$ is the geodetic distance in km, latitudes $\Phi_{P}$ and $\Phi_{X}$ are expressed in degrees, counted positive from the equatorial plane northwards and negative southwards, $\delta h$ is the difference in elevation between the point $\boldsymbol{P}$ and each of the stations $\boldsymbol{X}_{\boldsymbol{i}}$ (expressed in $\mathrm{km}$ ) and $f_{\text {oro }}$ is equal to 500. The closest station to the point $\boldsymbol{P}$ gives the cluster value to be assigned to $\boldsymbol{P}$. This interpolation procedure does not take into account natural limits that may have an influence on the radiation climate. For example, $\left(\mathrm{KT}_{\mathrm{d}}\right)_{\mathrm{m}}$ is a function of the elevation and the influence of a station located in an area of low elevation should be limited to this range of altitude. Accordingly, the initial map was manually corrected with the help of geographical atlases of Africa. Several publications (e.g., Anonymous 1994; Atlas of hydrometeorological data 1991; Bahraoui-Buret et al. 1983; Diabaté 1989; ESRA 2000; Raschke et al. 1991; WMO 1981) that indicate known radiation features were also considered.

\section{Results and discussions}

The final map is displayed in Fig. 3. The 20 classes (clusters) are reported by means of Roman numbers: I, II etc. Figures 4 to 7 display the monthly values of $\left(\mathrm{KT}_{\mathrm{d}}\right)_{\mathrm{m}}$ for each class. 
There is a marked latitudinal effect that is consistent with what is known of the climate of Africa and also of the distribution of $\left(\mathrm{KT}_{\mathrm{d}}\right)_{\mathrm{m}}$. One may see links between the known climates and the solar radiation climates shown in this figure. According to Trewartha (1954), the following rough climatic categories can be drawn for Africa (their codes are given in parenthesis):

- Rainy climate with no winter (A, Af, Am, Aw) - this tropical humid climate is present in tropical areas, e.g., Guinea, Senegal, Tanzania and Zaire, and marked by rainy climate with no winter. The coolest month is above $18^{\circ} \mathrm{C}$. It may be constantly moist: the rainfall of the driest month is at least 60 $\mathrm{mm}$ (Af, case of Zaire). A short dry season may occur that is compensated by heavy rain during the rest of the year (Am, Sierra Leone). The dry season may occur in winter (Aw, Guinea, Senegal, Tanzania).

- Dry climate (BS, BW, BSh, BWh, BShs, BShw) - The climate is dry and semi-arid (BS) or arid (BW, desert). It is warmer dry: all months are above $0^{\circ} \mathrm{C}(\mathrm{BSh}, \mathrm{BWh})$. The Kalahari Desert is an example of the semi-arid warmer dry climate (BSh), while Sudan and the Sahara are warmer dry deserts (BWh). There may be a dry season in winter (BShw, e.g. South-Sudan or South-Mauritania) or in summer (BShs, e.g., Tunisia).

- Rainy climate with mild winters $(\mathbf{C}, \mathbf{C b}, \mathbf{C s a}, \mathbf{C s b})$ - This climate is present in the Mediterranean basin, the Western coast of Morocco, the high plateaus of Ethiopia and South Africa. It is characterized by limited amplitude of the extreme temperatures: the coolest month is above $0^{\circ} \mathrm{C}$ but below $18^{\circ} \mathrm{C}$ and the warmest month is above $10^{\circ} \mathrm{C}$. In the Mediterranean area, the warmest month is above $22^{\circ} \mathrm{C}$ and the summer is dry (Csa). In Ethiopia or South Africa, the warmest month is below $22^{\circ} \mathrm{C}(\mathrm{Cb})$. The Southern extreme of Africa experiences dry season in summer (Csb).

Mapping of climates takes into account temperature and humidity. Our mapping does not, and this explains that there are several discrepancies between the weather climates and the solar radiation climates.

The Class I is found in the mountainous area Haut Atlas, in Morocco, and in the Southeast coast in the Limpopo plain. It is characterized by $\left(\mathrm{KT}_{\mathrm{d}}\right)_{\mathrm{m}}$ almost constant during the year, ranging between 0.53 and 0.59 , with a maximum in June-August (Fig. 4). In both areas, this period corresponds to the driest months. These areas have different weather climates: one is a rainy climate with mild winters (Csa for Morocco) and the other is a rainy climate with no winter (Aw, Limpopo plain). This mountainous area in Morocco exhibits lower $\left(\mathrm{KT}_{\mathrm{d}}\right)_{\mathrm{m}}$ than in other parts of Morocco. 
The Class II is located in the Southeast of Africa and is connected to a tropical humid climate (Aw) at elevations larger than $1000 \mathrm{~m}$ : Malawi and Madagascar. As for the previous class, $\left(\mathrm{KT}_{\mathrm{d}}\right)_{\mathrm{m}}$ is close to 0.55 during most of the year (Fig. 4), except in August-September when it reaches its maximum (0.63). These months are the driest ones. The Class III is observed in the high plateaus of Ethiopia, affected by rainy climate with mild winters $(\mathrm{Cb})$. Elevations are larger than $1000 \mathrm{~m}$. In summer, from November to March, $\left(\mathrm{KT}_{\mathrm{d}}\right)_{\mathrm{m}}$ is larger than or close to 0.7 with a peak to 0.72 in January (Fig. 4). The sky is usually very clear. For the rest of the year, $\left(\mathrm{KT}_{\mathrm{d}}\right)_{\mathrm{m}}$ is larger than 0.60 and reaches a minimum in April (0.58).

The Class IV is found on the high Sahara plateaus: Ahaggar, Air, Tibesti, of elevation larger than $1000 \mathrm{~m}$. The climate is dry and semi-arid (BShw). The sky is usually very clear. In boreal winter, from November to March, $\left(\mathrm{KT}_{\mathrm{d}}\right)_{\mathrm{m}}$ is larger than 0.70 and reaches a maximum of 0.74 in February, with the exception of December, where dust winds occur and decrease $\left(\mathrm{KT}_{\mathrm{d}}\right)_{\mathrm{m}}$ down to 0.66 (Fig. 4). For the remaining of the year, $\left(\mathrm{KT}_{\mathrm{d}}\right)_{\mathrm{m}}$ is always greater than 0.60 , except for June $(0.55)$ because of dust winds.

The Class V comprises two industrialized areas in semi-arid warmer dry climate with a boreal summer dry season (BShs): one in Morocco (city of Safi) and the other around the city of Cairo. Cairo is one of the largest cities in Africa (approximately 13 millions of inhabitants); it is the seat of industries and the traffic of vehicles is large. Despite pollution, evidenced by a large Linke turbidity factor between 4 and 6 (Diabate et al. 2003), the sky is very often clear and $\left(\mathrm{KT}_{\mathrm{d}}\right)_{\mathrm{m}}$ is large. It describes a perfect seasonal change with a minimum in December $(0.52)$ and a maximum in June (0.63, Fig. 4).

The Class VI is found in the high plateaus of Southeastern Africa, exhibiting rainy climate with mild winters (Cb). Elevations are greater than $1000 \mathrm{~m}$. It is also found along the Eastern Mediterranean coast and in the Western Sahel. $\left(\mathrm{KT}_{\mathrm{d}}\right)_{\mathrm{m}}$ is always greater than 0.5 (Fig. 5). It is minimum in December and increases in a gentle way to peak at 0.65 in June. This behavior is very close to that observed for Sicily in the ESRA.

The Class VII is limited to the arid Sinai Peninsula. The sky is very clear in boreal summer: $\left(\mathrm{KT}_{\mathrm{d}}\right)_{\mathrm{m}}$ is larger than 0.65 (Fig. 5). The lowest values of 0.55 are attained in November and December.

The Class VIII is found along the Western Mediterranean coast and in the Zaire basin. Both exhibit rainy climate and differ in winter, with mild winter along the Mediterranean coast $(\mathrm{Csa})$ and no winter for Zaire $(\mathrm{Af})$. $\left(\mathrm{KT}_{\mathrm{d}}\right)_{\mathrm{m}}$ is almost constant (0.50) from November to April and then peaks to 0.60 in June and July (Fig. 5). One may note that $\left(\mathrm{KT}_{\mathrm{d}}\right)_{\mathrm{m}}$ is much lower for this class than for the Class VI though both are found along the Mediterranean coast. 
The Class IX describes the major part of Morocco that is subjected to the influences of the Atlantic Ocean and extends towards the East in the mountain Atlas, except for the Haut Atlas (Class I). This is a rainy climate with mild winters (Csa). $\left(\mathrm{KT}_{\mathrm{d}}\right)_{\mathrm{m}}$ exhibits a bell-shaped form (Fig. 5). The maximum is 0.61 from June to August and the minimum is 0.49 in November.

The Class $\mathrm{X}$ is located in the Zaire low, where the climate is constantly moist $(\mathrm{Af}) .\left(\mathrm{KT}_{\mathrm{d}}\right)_{\mathrm{m}}$ is close to 0.5 , except during the dry season December-February where it closes to 0.6 (Fig. 5).

The Class XI is found in the Horn of Africa, along the ocean, exhibiting a dry climate (BWh), and in the humid tropical zone in Western Africa $(\mathrm{Aw}) .\left(\mathrm{KT}_{\mathrm{d}}\right)_{\mathrm{m}}$ is maximum in January (0.64, Fig. 6), decreases down to 0.47 in July and increases again.

The Class XII comprises desert areas in Sahara, Libya and Egypt with dry climate (BWh). The variations of $\left(\mathrm{KT}_{\mathrm{d}}\right)_{\mathrm{m}}$ are small (Fig. 6): it ranges between 0.58 in boreal winter and 0.67 in summer.

The Class XIII is a portion of the Western Sahara submitted to the influences of the Atlantic Ocean. The dry climate exhibits a dry season in summer (BShs). Thus, $\left(\mathrm{KT}_{\mathrm{d}}\right)_{\mathrm{m}}$ is the lowest in boreal winter though being larger than 0.55 (Fig. 6). It peaks in July - August with very large values of 0.70 .

The Class XIV is located in the Northern Sahara with a dry desert climate $(\mathrm{BWh})$. There is no season and $\left(\mathrm{KT}_{\mathrm{d}}\right)_{\mathrm{m}}$ is almost constant, ranging between 0.65 and 0.69 (Fig. 6).

The Class XV is found in many places: mountainous area in South Morocco (BShs), Eastern Sahara (BWh), coastal plains of Zambezi and Madagascar (Aw). $\left(\mathrm{KT}_{\mathrm{d}}\right)_{\mathrm{m}}$ exhibits little variation (Fig. 6): from 0.58 to 0.63 with highest values from March to June.

The Class XVI is made of the Kalahari and Namib deserts with a semi-arid warmer dry climate (BSh). Along the coast, fog may occur. Low values (0.60) are observed in April to June, then it rises up to 0.67 in September, drops down to 0.6 in October and rises again up to 0.65 in December, then gently decreases down to 0.6 in April (Fig. 7).

The Class XVII is found in Western Sahara (BWh) and in the Southern part of the Luanda plateau with elevation greater than $1000 \mathrm{~m}(\mathrm{Aw})$. There is a marked seasonal variation in $\left(\mathrm{KT}_{\mathrm{d}}\right)_{\mathrm{m}}$ (Fig. 7). A minimum of 0.46 is observed in December - January. The maximum of 0.68 is attained from June to September.

The Class XVIII is the Southeastern part of the Sahel. The climate is dry and semi-arid with a dry season in winter (BShw). This is reflected by $\left(\mathrm{KT}_{\mathrm{d}}\right)_{\mathrm{m}}$ (Fig. 7). The values are very large as a whole. A maximum of 0.69 is found in December - January and a minimum of 0.52 in July. Owing to one reviewer, we found a series of monthly means of daily irradiation for fourteen stations in Sudan in Khogali (1983). After conversion into $\left(\mathrm{KT}_{\mathrm{d}}\right)_{\mathrm{m}}$, by reporting them onto the map, we found that twelve of them are in full agreement with the class (values and shape) 
to which they belong ( 9 sites in Class 18, 1 in Class 11, 1 in Class 14 and 1 in Class 15). While it should be in Class 18 , one belongs to Class 16 that is not present in this part of the map, and one does not belong to any class. Though of limited extension, these results mainly support our zoning.

The Class XIX is the Northern part of the Luanda plateau with elevation greater than $1000 \mathrm{~m} .\left(\mathrm{KT}_{\mathrm{d}}\right)_{\mathrm{m}}$ is the lowest in February (0.33) then rises up to 0.58 from June to August (Fig. 7).

The Class XX is located in the equatorial zone, North of the Gulf of Guinea. The climate is constantly moist with a dry season during the boreal winter $(\mathrm{Aw}) .\left(\mathrm{KT}_{\mathrm{d}}\right)_{\mathrm{m}}$ is almost constant from November to May at approximately 0.45 (Fig. 7). Then it decreases to 0.32 in August and then increases again.

\section{Conclusion}

This work provides a first estimate of the solar radiation climate in Africa. Based on an approach adopted for Europe, it permits to increase the knowledge available in Africa in agreement with preliminary studies and other atlases.

The climate zone classification only gives information about similar values of the monthly mean of the daily clearness index. It is therefore unsuitable for direct energy calculations. If the user wants to make energy calculations he is recommended to use a representative station of a zone for his site or for a selected geographical position. Otherwise, he can use the readings in Table 2, selecting a station from the map and Table 3. Climatological monthly mean of $\left(\mathrm{G}_{0 \mathrm{~d}}\right)_{\mathrm{m}}$ can be found at the SoDa Web site (see at http://www.soda-is.com and follow the link on the simulation of the clear-sky irradiation). Using the monthly mean of the daily clearness index of a representative site and multiplying by $\left(\mathrm{G}_{0 \mathrm{~d}}\right)_{\mathrm{m}}$ for the user site or geographical position one obtains the desired monthly mean of the daily global irradiation.

Twenty climatic areas were identified. This number comes from pure mathematics. The links between these 20 solar radiation climates and the climates known for Africa from e.g., Trewartha (1954), are sometimes obvious, sometimes not. This is explained by the fact that the solar radiation is not the only parameter driving the climate. This lack of strong relationship between the climate and the solar radiation climate was already evidenced in the ESRA.

The authors are aware of the limitations of such a zoning. Looking at the map, it is obvious that the denser the network of stations, the more detailed the zoning. For areas with a few or no stations, the zones are very large. The reason is clearly the lack of stations. One way to increase the quality of the zoning would be to use satellite- derived 
clearness index, which would be thus available at each pixel within the whole area. Such a dataset did not exist at the time of the work. It would have also implied much larger computational resources.

As the clearness index depends on the cloud coverage and of the optical thickness of the atmosphere, including the turbidity of the air mass, the separate influences of the cloudiness and of the turbidity upon the irradiation may become not evident in the clearness index. Therefore, a future improvement of this zoning process would be to use additional information in the clustering process. This information might be the cloudiness (see e.g., Atlas of hydrometeorological data 1991), or the Linke turbidity factor, which is not currently mapped.

Finally, it should be mentioned that the topography near to a site - the presence of mountains or the ocean - could cause a local area to be significantly different from the region as a whole. The present map cannot reproduce these micro-climatic effects.

The map presented here should be considered as a first attempt to describe the solar radiation climate in Africa. International efforts are on their way, such as the creation of the database HelioClim (Lefèvre et al. 2002b; Rigollier, Wald 1999), which aims at providing time-series of daily irradiation for Africa since 1985 through the SoDa Web service (Wald 2000; Wald et al. 2002) or the project SWERA (Sun and Wind Energy Resource Assessment, see reference SWERA).

\section{Acknowledgements}

This work was partly supported by the Service de Coopération et d'Action Culturelle de l'Ambassade de France au Mali. We are thankful to Djénéba Tounkara and Rokia Berthé for the manual digitizing of the data used in this study. We thank one of the reviewers whose comments improve the quality of the paper.

\section{References}

Anonymous, 1994. SRB (Surface Radiation Budget) dataset document. NASA Langley Research Center, Maryland, USA.

Atlas of Hydrometeorological Data - Europe, 1991. In Russian. Published by Army Publishing House, Moscow, Russia, 371p.

Ba, M., Nicholson, S., Frouin, R., 2001. Satellite-derived surface radiation budget over the African continent. Part II: Climatologies of the various components. Journal of Climate 14, 60-76.

Bahraoui-Buret, J., Bargach, M. N., Ben Kaddour, M. L., 1983. Le Gisement Solaire Marocain, SMER, Rabat, Morocco, $111 \mathrm{p}$.

Beyer, H.-G., Czeplak, G., Terzenbach, U., Wald, L., 1997. Assessment of the method used to construct clearness index maps for the new European solar radiation atlas (ESRA). Solar Energy 61, 389-397.

Diabaté, L., 1989. Détermination du rayonnement solaire à l'aide d'images satellitaires. Thèse de Doctorat en Sciences, Ecole Nationale Supérieure des Mines de Paris, Paris, France.

Diabaté, L., Remund, J., Wald, L., 2003. Linke turbidity factors for several sites in Africa. Solar Energy 75, 111119. 
Dogniaux, R., Lemoine, M., 1983. Classification of radiation sites in terms of different indices of atmospheric transparency. In: Palz W. (Ed.), Solar Energy R\&D in the European Community, Series F, Vol. 2, Solar Energy Data. D. Reidel Publ. Co., Dordecht, 94-107.

ESRA, 2000. European Solar Radiation Atlas, includ. CD-ROM. Edited by J. Greif, K. Scharmer. Published for the Commission of the European Communities by Presses de l'Ecole, Ecole des Mines de Paris, France.

Geiger, M., Diabaté, L., Ménard, L., Wald, L., 2003. A web service for controlling the quality of global solar radiation irradiation. Solar Energy 73, 475-480.

Khogali, A., 1983. Solar radiation over Sudan - Comparison of measured and predicted data. Solar Energy 31, 45-43.

Lefèvre, M., Remund, J., Albuisson, M., Wald, L., 2002a. Study of effective distances for interpolation schemes in meteorology. In: European Geophysical Society, 27th General Assembly, Geophysical Research Abstracts, vol. 4, April 2002, EGS02-A-03429.

Lefèvre, M., Rigollier, C., Cros, S., Albuisson, M., Wald, L., 2002b. A shortwave radiation database to support GODAE-related activities. In: Proceedings of the International Symposium "En route to GODAE", 13-15 June 2002, Biarritz, France. Published by CNES, Toulouse, France, 2002, pp. 157-158.

Raschke, E., Stuhlmann, R., Palz, W., Steemers, T. C., 1991. Solar Radiation Atlas of Africa. Published for the Commission of the European Communities by A. A. Balkema. ISBN 90-54-5410, 155 pp.

Rigollier, C., Wald, L., 1999. The HelioClim Project: from satellite images to solar radiation maps. In: Proceedings of the ISES Solar World Congress 1999, Jerusalem, Israel, July 4-9, 1999, volume I, pp 427-431. SWERA (Sun and Wind Energy Resource Assessment), An UNEP project, see at http://swera.unep.net Thompson, R., Perry, A. Eds, 1997. Applied Climatology: principles and practice. Routledge, London, 352 pp. Trewartha, G. T., 1954. An Introduction to Climate. 3rd ed. McGraw Hill Book Co.

Wald, L., 2000. SoDa: a project for the integration and exploitation of networked solar radiation databases. In: Proceedings of the European Geophysical Society Meeting, XXV General Assembly, Nice, France, 25-29 April 2000 (CD-ROM).

Wald, L., Albuisson, M., Best, C., Delamare, C., Dumortier, D., Gaboardi, E., Hammer, A., Heinemann, D., Kift, R., Kunz, S., Lefèvre, M., Leroy, S., Martinoli, M., Ménard, L., Page, J., Prager, T., Ratto, C., Reise, C., Remund, J., Rimoczi-Paal, A., Van der Goot, E., Vanroy, F., Webb, A., 2002. SoDa: a project for the integration and exploitation of networked solar radiation databases. In: Environmental Communication in the Information Society, W. Pillmann, K. Tochtermann Eds, Part 2, pp. 713-720. Published by the International Society for Environmental Protection, Vienna, Austria.

Ward, J. W., 1963. Hierarchical grouping to optimize an objective function. Journal American Statistics Association 58, 236-244.

WMO, World Meteorological Organization, 1981. Meteorological aspects of the utilization of solar radiation as an energy source. WMO technical Note No 172, WMO ref. 557, Geneva, Switzerland, 298 pp.

WMO, World Meteorological Organization, 1998. 1961-1990 global climate normals (CLINO). CD-ROM version 1.0, November 1998. Produced by National Climatic Data Center, NOAA, USA.

WMO, World Meteorological Organization, 2002. WMO - No 9, Weather Reporting - Observing Stations, Vol. A. Published by WMO, Geneva, Switzerland.

WRDC (World Radiation Data Center) Data Access, see on-line at http://wrdcmgo.nrel.gov/html/data_access.html 


\begin{tabular}{|c|c|c|c|c|c|}
\hline Station Name (country) & Latitude & Longitude & $\begin{array}{c}\text { Elevation } \\
(\mathbf{m})\end{array}$ & $\begin{array}{c}\text { Period of } \\
\text { Measurement }\end{array}$ & WMO-Nr \\
\hline Nador (Morocco) & 35.15 & -2.92 & 7 & 1994-1998 & 6340 \\
\hline El Aaiun (Western Sahara) & 27.17 & -13.22 & 64 & 1994-1998 & 60033 \\
\hline Tanger (Morocco) & 35.72 & -5.92 & 16 & 1994-1998 & 60101 \\
\hline Larache (Morocco) & 35.17 & -6.12 & 47 & 1994-1998 & 60105 \\
\hline Al Hoceima (Morocco) & 35.17 & -3.85 & 12 & 1994-1998 & 60107 \\
\hline Oujda (Morocco) & 34.77 & -1.92 & 465 & 1994-1998 & 60115 \\
\hline Kenitra (Morocco) & 34.30 & -6.60 & 5 & 1994-1998 & 60120 \\
\hline Rabat-Sale (Morocco) & 34.50 & -6.77 & 76 & 1994-1998 & 60135 \\
\hline Casablanca (Morocco) & 33.57 & -7.67 & 67 & 1994-1998 & 60155 \\
\hline Nouasseur (Morocco) & 33.37 & -7.57 & 200 & 1994-1998 & 60156 \\
\hline El Jadida (Morocco) & 33.22 & -8.52 & 270 & 1994-1998 & 60165 \\
\hline Safi (Morocco) & 32.27 & -9.22 & 45 & 1994-1998 & 60185 \\
\hline Beni Mellal (Morocco) & 32.37 & -6.40 & 468 & 1994-1998 & 60191 \\
\hline Essaouira (Morocco) & 31.52 & -9.77 & 7 & 1994-1998 & 60220 \\
\hline Marrakech (Morocco) & 31.78 & -8.20 & 467 & 1994-1998 & 60230 \\
\hline Agadir (Morocco) & 30.37 & -9.40 & 32 & 1994-1998 & 60250 \\
\hline Ouarzazate (Morocco) & 30.92 & -6.90 & 1136 & 1994-1998 & 60265 \\
\hline Tetouan (Morocco) & 35.57 & -5.32 & 5 & 1994-1998 & 60318 \\
\hline Tamanrasset (Algeria) & 22.78 & 5.52 & 1377 & 1995-1999 & 60680 \\
\hline Sidi Barrani (Egypt) & 31.63 & 25.85 & 26 & 1994-1998 & 62301 \\
\hline Mersa Matruh (Egypt) & 31.33 & 27.22 & 38 & 1995-1998 & 62306 \\
\hline Rafah (Egypt) & 31.22 & 34.20 & 73 & 1994-1998 & 62335 \\
\hline El Arish (Egypt) & 31.12 & 33.75 & 32 & 1994-1998 & 62337 \\
\hline Tahrir (Egypt) & 30.65 & 30.70 & 19 & 1994-1998 & 62345 \\
\hline Bahtim (Egypt) & 30.15 & 31.25 & 17 & 1994-1998 & 62369 \\
\hline Cairo (Egypt) & 30.08 & 31.28 & 36 & 1994-1998 & 62371 \\
\hline Asyut (Egypt) & 27.20 & 31.50 & 52 & 1994-1998 & 62392 \\
\hline Aswan (Egypt) & 23.97 & 32.78 & 192 & 1994-1998 & 62414 \\
\hline Wenchi (Ghana) & 7.75 & -2.10 & 339 & 1994-1998 & 65432 \\
\hline Tete (Mozambique) & -16.18 & 33.58 & 123 & 1994-1998 & 67261 \\
\hline Maputo (Mozambique) & -25.97 & 32.60 & 70 & 1994-1998 & 67341 \\
\hline Mansa (Zambia) & -11.10 & 28.85 & 1259 & 1994-1998 & 67461 \\
\hline Lusaka (Zambia) & -15.42 & 28.32 & 1280 & 1994-1998 & 67666 \\
\hline Harare (Zimbabwe) & -17.83 & 31.02 & 1471 & 1994-1998 & 67774 \\
\hline Bulawayo (Zimbabwe) & -20.15 & 28.62 & 1343 & 1994-1998 & 67964 \\
\hline Sidi Bou Said (Tunisia) & 36.87 & 10.23 & 127 & 1994-1998 & No Index \\
\hline Sunsatorange (South Africa) & -31.25 & 26.25 & & 1985-1986 & No Index \\
\hline Sunsat35 (Botswana) & -23.75 & 23.75 & & 1985-1986 & No Index \\
\hline Sunsat36 (Mozambique) & -16.25 & 36.25 & & $1985-1986$ & No Index \\
\hline Sunsat33 (Zaire) & -6.25 & 21.25 & & 1985-1986 & No Index \\
\hline Sunsat30 (Zaire) & 1.25 & 21.25 & & 1985-1986 & No Index \\
\hline Sunsat37 (Kenya) & 1.25 & 41.25 & & 1985-1986 & No Index \\
\hline Sunsat34 (Côte d'Ivoire) & 6.25 & -8.75 & & $1985-1986$ & No Index \\
\hline Sunsat31 (Ghana) & 8.75 & -1.25 & & $1985-1986$ & No Index \\
\hline Sunsat29 (Ethiopia) & 8.75 & 41.25 & & 1985-1986 & No Index \\
\hline Sunsat32 (Chad) & 11.25 & 21.25 & & $1985-1986$ & No Index \\
\hline Sunsat28 (Sudan) & 11.25 & 28.75 & & $1985-1986$ & No Index \\
\hline Sunsat27 (Mali) & 16.25 & -6.25 & & $1985-1986$ & No Index \\
\hline Sunsat25 (Sudan) & 16.25 & 28.75 & & $1985-1986$ & No Index \\
\hline Sunsat-1625/2125 (Mauritania) & 21.25 & -16.25 & & $1985-1986$ & No Index \\
\hline Sunsat23 (Chad) & 21.25 & 18.75 & & $1985-1986$ & No Index \\
\hline Sunsat26 (Mali) & 23.75 & -6.25 & & 1985-1986 & No Index \\
\hline Sunsat24 (Algeria) & 23.75 & 6.25 & & $1985-1986$ & No Index \\
\hline Sunsat-625/3375 (Morocco) & 33.75 & -6.25 & & 1981-1990 & No Index \\
\hline ESRA 2700/300 (Algeria) & 27.00 & 3.00 & & 1981-1990 & No Index \\
\hline ESRA 2875/2875 (Egypt) & 28.75 & 28.75 & & 1981-1990 & No Index \\
\hline ESRA2900/1800 (Libyan Arab Jamahiriya) & 29 & 18 & & $1981-1990$ & No Index \\
\hline ESRA3000/1800 (Libyan Arab Jamahiriya) & 30 & 18 & & $1981-1990$ & No Index \\
\hline
\end{tabular}




\begin{tabular}{lrrrr}
\hline ESRA3000/2000 (Libyan Arab Jamahiriya) & 30.00 & 20.00 & $1981-1990$ & No Index \\
\hline ESRA 3025/3025 (Egypt) & 30.25 & 30.25 & $1981-1990$ & No Index \\
\hline ESRA3100/2400 (Libyan Arab Jamahiriya) & 31 & 24 & $1981-1990$ & No Index \\
\hline ESRA 3125/3125 (Egypt) & 31.25 & 31.25 & $1981-1990$ & No Index \\
\hline
\end{tabular}

Table 1. Description of the 62 stations and other sites. They are ranked by WMO number and then by latitude. Country nomenclature is that of WMO (2002)

\begin{tabular}{|c|c|c|c|c|c|c|c|c|c|c|c|c|}
\hline Station Name & Jan. & Feb. & Mar. & Apr. & May & Jun. & Jul. & Aug. & Sep. & Oct. & Nov. & Dec. \\
\hline Nador & 0.51 & 0.51 & 0.54 & 0.54 & 0.60 & 0.61 & 0.60 & 0.57 & 0.55 & 0.54 & 0.50 & 0.51 \\
\hline El Aaiun & 0.57 & 0.57 & 0.61 & 0.63 & 0.62 & 0.63 & 0.61 & 0.60 & 0.56 & 0.57 & 0.57 & 0.54 \\
\hline Tanger & 0.51 & 0.50 & 0.57 & 0.54 & 0.59 & 0.62 & 0.56 & 0.62 & 0.59 & 0.55 & 0.48 & 0.50 \\
\hline Larache & 0.49 & 0.50 & 0.56 & 0.54 & 0.58 & 0.61 & 0.63 & 0.62 & 0.59 & 0.54 & 0.47 & 0.48 \\
\hline Al Hoceima & 0.52 & 0.51 & 0.53 & 0.52 & 0.57 & 0.59 & 0.60 & 0.57 & 0.54 & 0.56 & 0.48 & 0.51 \\
\hline Oujda & 0.52 & 0.52 & 0.56 & 0.54 & 0.59 & 0.61 & 0.63 & 0.61 & 0.58 & 0.55 & 0.50 & 0.51 \\
\hline Kenitra & 0.49 & 0.50 & 0.56 & 0.57 & 0.61 & 0.62 & 0.63 & 0.62 & 0.58 & 0.54 & 0.48 & 0.48 \\
\hline Rabat-Sale & 0.52 & 0.51 & 0.58 & 0.57 & 0.60 & 0.61 & 0.63 & 0.62 & 0.60 & 0.56 & 0.51 & 0.52 \\
\hline Casablanca & 0.52 & 0.51 & 0.57 & 0.58 & 0.61 & 0.60 & 0.60 & 0.60 & 0.58 & 0.55 & 0.50 & 0.51 \\
\hline Nouasseur & 0.52 & 0.52 & 0.57 & 0.55 & 0.59 & 0.62 & 0.63 & 0.62 & 0.60 & 0.55 & 0.50 & 0.52 \\
\hline El Jadida & 0.52 & 0.52 & 0.57 & 0.58 & 0.61 & 0.59 & 0.59 & 0.58 & 0.57 & 0.54 & 0.49 & 0.51 \\
\hline Safi & 0.56 & 0.55 & 0.59 & 0.59 & 0.61 & 0.61 & 0.62 & 0.61 & 0.57 & 0.55 & 0.51 & 0.54 \\
\hline Beni Mellal & 0.56 & 0.52 & 0.60 & 0.56 & 0.58 & 0.60 & 0.58 & 0.59 & 0.58 & 0.57 & 0.54 & 0.55 \\
\hline Essaouira & 0.54 & 0.53 & 0.56 & 0.58 & 0.58 & 0.61 & 0.59 & 0.59 & 0.56 & 0.53 & 0.50 & 0.51 \\
\hline Marrakech & 0.58 & 0.56 & 0.58 & 0.58 & 0.58 & 0.59 & 0.64 & 0.62 & 0.57 & 0.55 & 0.56 & 0.57 \\
\hline Agadir & 0.57 & 0.55 & 0.58 & 0.59 & 0.58 & 0.58 & 0.56 & 0.56 & 0.53 & 0.54 & 0.52 & 0.56 \\
\hline Ouarzazate & 0.63 & 0.62 & 0.64 & 0.65 & 0.63 & 0.65 & 0.63 & 0.60 & 0.57 & 0.58 & 0.59 & 0.61 \\
\hline Tetouan & 0.52 & 0.49 & 0.51 & 0.51 & 0.59 & 0.61 & 0.62 & 0.60 & 0.54 & 0.56 & 0.46 & 0.49 \\
\hline Tamanrasset & 0.71 & 0.74 & 0.70 & 0.68 & 0.63 & 0.55 & 0.66 & 0.63 & 0.63 & 0.61 & 0.70 & 0.66 \\
\hline Sidi Barrani & 0.56 & 0.60 & 0.60 & 0.61 & 0.64 & 0.64 & 0.66 & 0.65 & 0.63 & 0.58 & 0.55 & 0.51 \\
\hline Mersa Matruh & 0.54 & 0.57 & 0.59 & 0.61 & 0.64 & 0.65 & 0.64 & 0.64 & 0.62 & 0.57 & 0.50 & 0.51 \\
\hline Rafah & 0.57 & 0.59 & 0.62 & 0.64 & 0.66 & 0.67 & 0.65 & 0.64 & 0.62 & 0.59 & 0.55 & 0.56 \\
\hline El Arish & 0.58 & 0.62 & 0.63 & 0.64 & 0.66 & 0.68 & 0.66 & 0.65 & 0.62 & 0.58 & 0.55 & 0.56 \\
\hline Tahrir & 0.56 & 0.58 & 0.58 & 0.62 & 0.64 & 0.66 & 0.64 & 0.63 & 0.62 & 0.57 & 0.54 & 0.54 \\
\hline Bahtim & 0.54 & 0.56 & 0.58 & 0.61 & 0.63 & 0.64 & 0.63 & 0.61 & 0.59 & 0.56 & 0.52 & 0.51 \\
\hline Cairo & 0.54 & 0.56 & 0.58 & 0.61 & 0.62 & 0.63 & 0.61 & 0.60 & 0.59 & 0.55 & 0.52 & 0.50 \\
\hline Asyut & 0.63 & 0.67 & 0.68 & 0.67 & 0.66 & 0.68 & 0.66 & 0.65 & 0.64 & 0.61 & 0.59 & 0.59 \\
\hline Aswan & 0.68 & 0.72 & 0.68 & 0.68 & 0.65 & 0.68 & 0.66 & 0.65 & 0.63 & 0.64 & 0.65 & 0.66 \\
\hline Wenchi & 0.45 & 0.49 & 0.47 & 0.44 & 0.44 & 0.39 & 0.35 & 0.31 & 0.34 & 0.43 & 0.49 & 0.44 \\
\hline Tete & 0.54 & 0.60 & 0.63 & 0.62 & 0.61 & 0.61 & 0.58 & 0.61 & 0.57 & 0.59 & 0.60 & 0.58 \\
\hline Maputo & 0.57 & 0.59 & 0.57 & 0.58 & 0.58 & 0.61 & 0.60 & 0.60 & 0.58 & 0.52 & 0.51 & 0.57 \\
\hline Mansa & 0.39 & 0.33 & 0.40 & 0.48 & 0.54 & 0.59 & 0.58 & 0.58 & 0.54 & 0.51 & 0.47 & 0.38 \\
\hline Lusaka & 0.46 & 0.45 & 0.55 & 0.61 & 0.63 & 0.64 & 0.63 & 0.64 & 0.63 & 0.59 & 0.54 & 0.49 \\
\hline Harare & 0.46 & 0.49 & 0.55 & 0.58 & 0.60 & 0.62 & 0.62 & 0.63 & 0.64 & 0.60 & 0.55 & 0.44 \\
\hline Bulawayo & 0.51 & 0.57 & 0.61 & 0.64 & 0.62 & 0.66 & 0.63 & 0.65 & 0.63 & 0.59 & 0.54 & 0.52 \\
\hline Sidi Bou Said & 0.50 & 0.54 & 0.56 & 0.54 & 0.59 & 0.60 & 0.57 & 0.59 & 0.55 & 0.55 & 0.49 & 0.51 \\
\hline Sunsatorange & 0.63 & 0.61 & 0.62 & 0.59 & 0.62 & 0.58 & 0.62 & 0.64 & 0.66 & 0.58 & 0.63 & 0.67 \\
\hline Sunsat35 & 0.63 & 0.62 & 0.59 & 0.58 & 0.62 & 0.61 & 0.63 & 0.65 & 0.66 & 0.62 & 0.64 & 0.62 \\
\hline Sunsat36 & 0.53 & 0.55 & 0.56 & 0.55 & 0.58 & 0.55 & 0.57 & 0.62 & 0.63 & 0.60 & 0.55 & 0.51 \\
\hline Sunsat33 & 0.51 & 0.50 & 0.51 & 0.49 & 0.57 & 0.62 & 0.63 & 0.60 & 0.55 & 0.50 & 0.52 & 0.49 \\
\hline Sunsat30 & 0.59 & 0.58 & 0.52 & 0.52 & 0.51 & 0.52 & 0.49 & 0.53 & 0.48 & 0.47 & 0.51 & 0.58 \\
\hline Sunsat37 & 0.64 & 0.65 & 0.60 & 0.56 & 0.54 & 0.50 & 0.49 & 0.53 & 0.53 & 0.54 & 0.54 & 0.60 \\
\hline Sunsat34 & 0.64 & 0.60 & 0.58 & 0.56 & 0.54 & 0.51 & 0.43 & 0.45 & 0.50 & 0.52 & 0.56 & 0.63 \\
\hline Sunsat31 & 0.66 & 0.64 & 0.61 & 0.60 & 0.57 & 0.55 & 0.47 & 0.47 & 0.48 & 0.58 & 0.61 & 0.64 \\
\hline Sunsat29 & 0.73 & 0.69 & 0.69 & 0.58 & 0.65 & 0.63 & 0.63 & 0.64 & 0.63 & 0.66 & 0.69 & 0.69 \\
\hline Sunsat32 & 0.68 & 0.66 & 0.67 & 0.67 & 0.63 & 0.59 & 0.52 & 0.57 & 0.57 & 0.65 & 0.67 & 0.68 \\
\hline Sunsat28 & 0.69 & 0.70 & 0.68 & 0.66 & 0.63 & 0.58 & 0.52 & 0.55 & 0.58 & 0.65 & 0.67 & 0.69 \\
\hline Sunsat27 & 0.51 & 0.57 & 0.62 & 0.61 & 0.63 & 0.63 & 0.60 & 0.62 & 0.60 & 0.58 & 0.55 & 0.50 \\
\hline Sunsat25 & 0.62 & 0.63 & 0.65 & 0.61 & 0.63 & 0.62 & $\begin{array}{l}0.59 \\
\end{array}$ & 0.60 & 0.60 & 0.62 & 0.58 & 0.58 \\
\hline
\end{tabular}




\begin{tabular}{lllllllllllll}
\hline Sunsat-1625/2125 & 0.55 & 0.55 & 0.57 & 0.60 & 0.65 & 0.69 & 0.69 & 0.70 & 0.69 & 0.57 & 0.59 & 0.60 \\
\hline Sunsat23 & 0.65 & 0.67 & 0.67 & 0.71 & 0.70 & 0.70 & 0.69 & 0.68 & 0.66 & 0.68 & 0.65 & 0.66 \\
\hline Sunsat26 & 0.56 & 0.56 & 0.64 & 0.65 & 0.67 & 0.66 & 0.66 & 0.65 & 0.62 & 0.58 & 0.55 & 0.53 \\
\hline Sunsat24 & 0.59 & 0.62 & 0.65 & 0.68 & 0.70 & 0.68 & 0.70 & 0.71 & 0.65 & 0.62 & 0.61 & 0.59 \\
\hline Sunsat-625/3375 & 0.58 & 0.56 & 0.60 & 0.60 & 0.60 & 0.69 & 0.71 & 0.72 & 0.70 & 0.67 & 0.59 & 0.56 \\
\hline ESRA 2700/300 & 0.70 & 0.68 & 0.66 & 0.68 & 0.67 & 0.66 & 0.68 & 0.69 & 0.66 & 0.67 & 0.68 & 0.65 \\
\hline ESRA 2875/2875 & 0.58 & 0.62 & 0.64 & 0.65 & 0.65 & 0.66 & 0.66 & 0.66 & 0.66 & 0.63 & 0.60 & 0.55 \\
\hline ESRA2900/1800 & 0.59 & 0.63 & 0.64 & 0.64 & 0.63 & 0.64 & 0.67 & 0.66 & 0.65 & 0.64 & 0.61 & 0.57 \\
\hline ESRA3000/1800 & 0.58 & 0.61 & 0.62 & 0.63 & 0.63 & 0.65 & 0.67 & 0.67 & 0.65 & 0.63 & 0.60 & 0.57 \\
\hline ESRA3000/2000 & 0.57 & 0.61 & 0.62 & 0.63 & 0.62 & 0.64 & 0.67 & 0.67 & 0.65 & 0.63 & 0.60 & 0.56 \\
\hline ESRA 3025/3025 & 0.55 & 0.57 & 0.60 & 0.63 & 0.64 & 0.67 & 0.67 & 0.65 & 0.65 & 0.60 & 0.56 & 0.52 \\
\hline
\end{tabular}

Table 2. Clearness indices for the 62 sites and each month

\begin{tabular}{cl}
\hline Zone Number & \multicolumn{1}{c}{ Station Name (country) } \\
\hline 1 & Agadir, Beni Mellal, Maputo, Marrakech \\
\hline 2 & Sunsat36 \\
\hline 3 & Sunsat29 \\
\hline 4 & Tamanrasset \\
\hline 5 & Bahtim, Cairo, Safi \\
\hline 6 & Bulawayo, ESRA 3025/3025, ESRA 3125/3125, \\
& SSRA3100/2400, Mersa Matruh, Sidi Barrani, \\
\hline 7 & El Arish, Rahrir, Sunsat26 \\
\hline 8 & Al Hoceima, Nador, Sidi Bou Said, Sunsat33, \\
\hline 9 & Tetouan \\
\hline 10 & Casablanca, El Jadida, Essaouira, Kenitra, Larache, \\
\hline 11 & Souasseur, Oujda, Rabat-Sale, Tanger \\
\hline 12 & Sunsat30 1, Sunsat34, Sunsat37 \\
\hline 13 & Asyut, ESRA 2875/2875, ESRA2900/1800, \\
\hline 14 & Sunsat-1625/2125, Sunsat-625/3375 \\
\hline 15 & Aswan, ESRA 2700/300, Sunsat23 \\
\hline 16 & El Aaiun, Ouarzazate, Sunsat25, Tete \\
\hline 17 & Sunsat35, Sunsatorange \\
\hline 18 & Harare, Lusaka \\
\hline 19 & Sunsat28, Sunsat32 \\
\hline 20 & Mansa \\
\hline & Wenchi \\
\hline
\end{tabular}

Table 3. List of the stations for each zone 


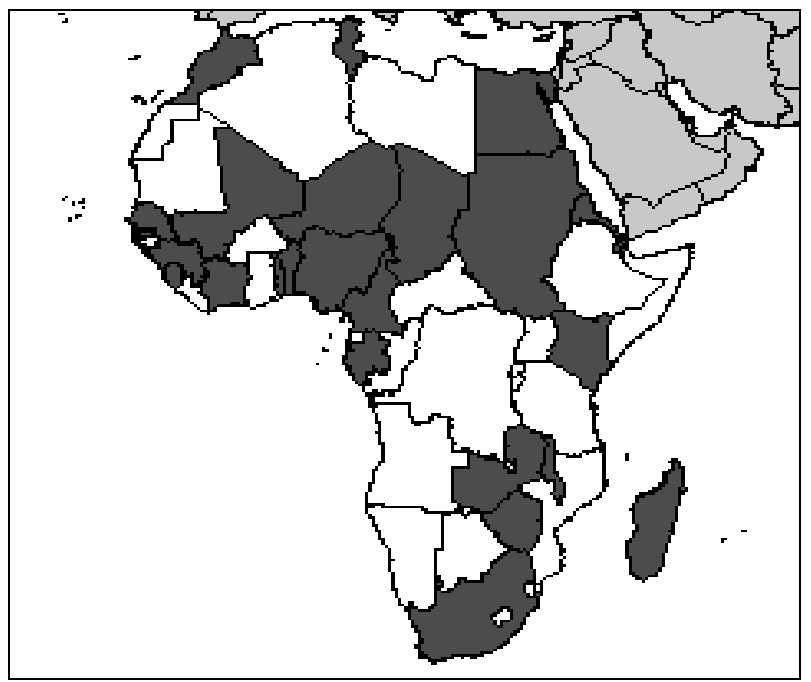

Figure 1. African countries (in dark gray) for which sunshine duration normals are available in the CLINO. Excerpt of an image within the CLINO CD-ROM (WMO 1988)

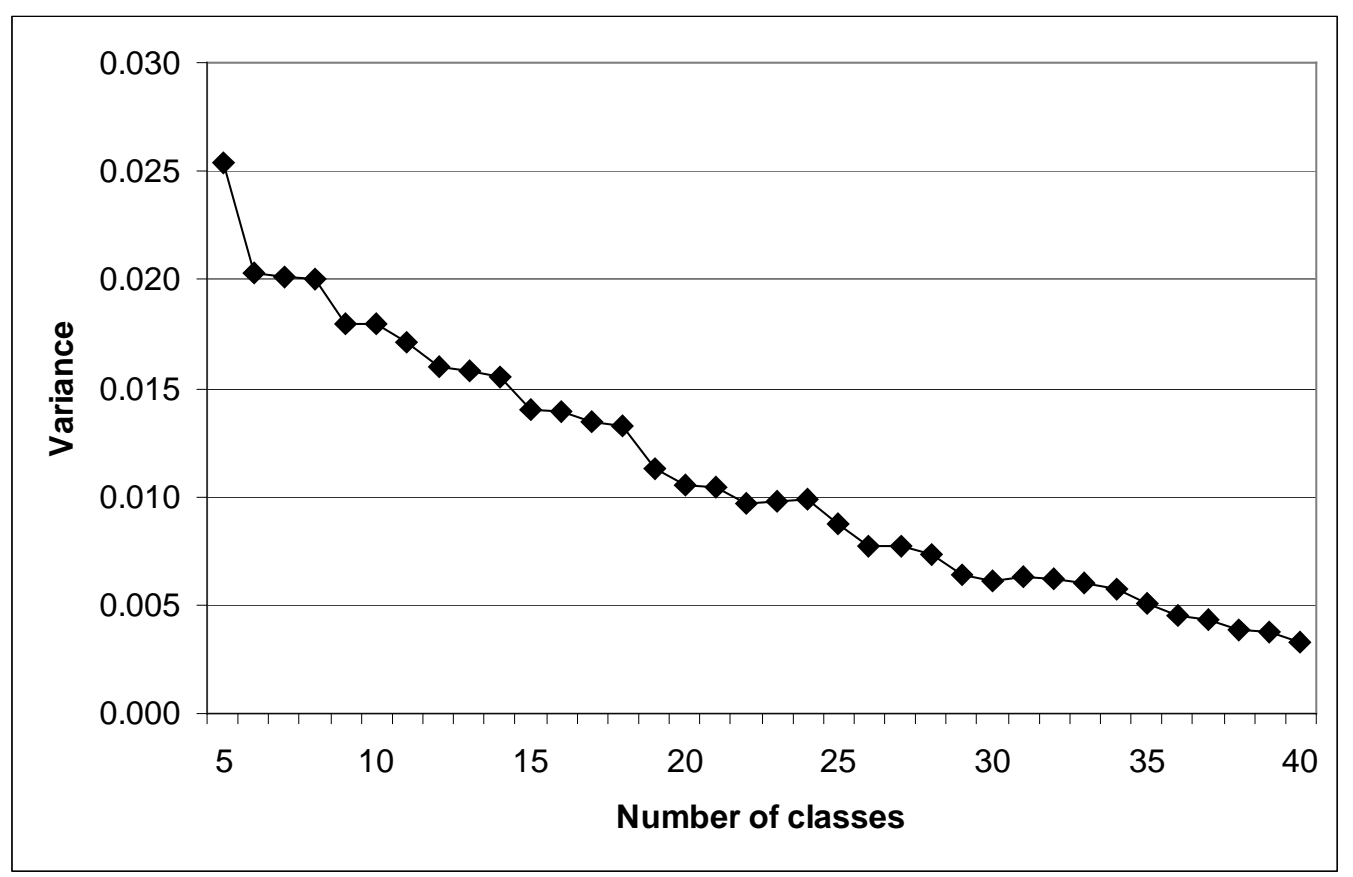

Figure 2. Overall heterogeneity within the clusters as a function of the number of classes 


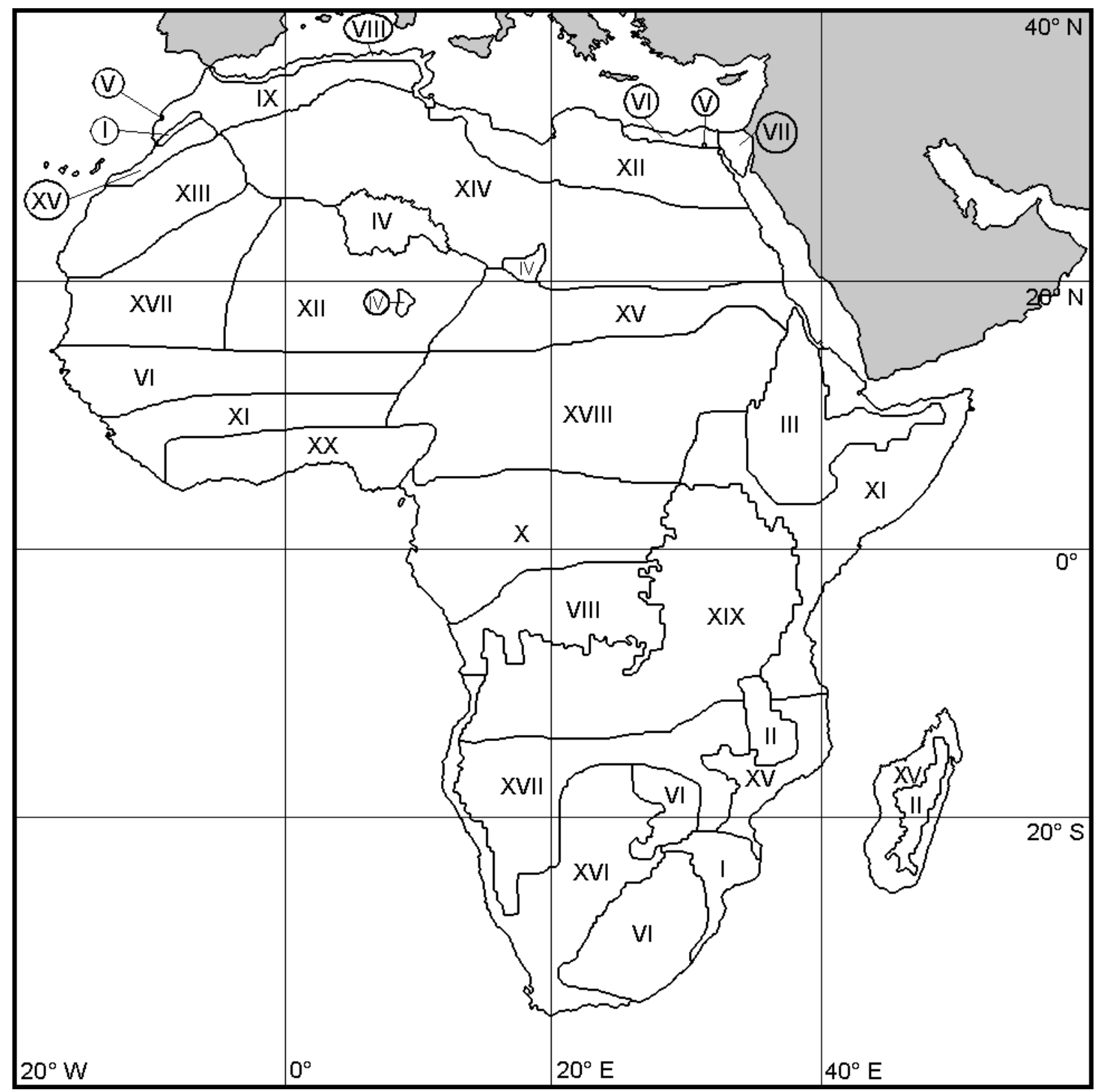

Figure 3. Map of the 20 solar radiation climate zones, in roman numbers. 


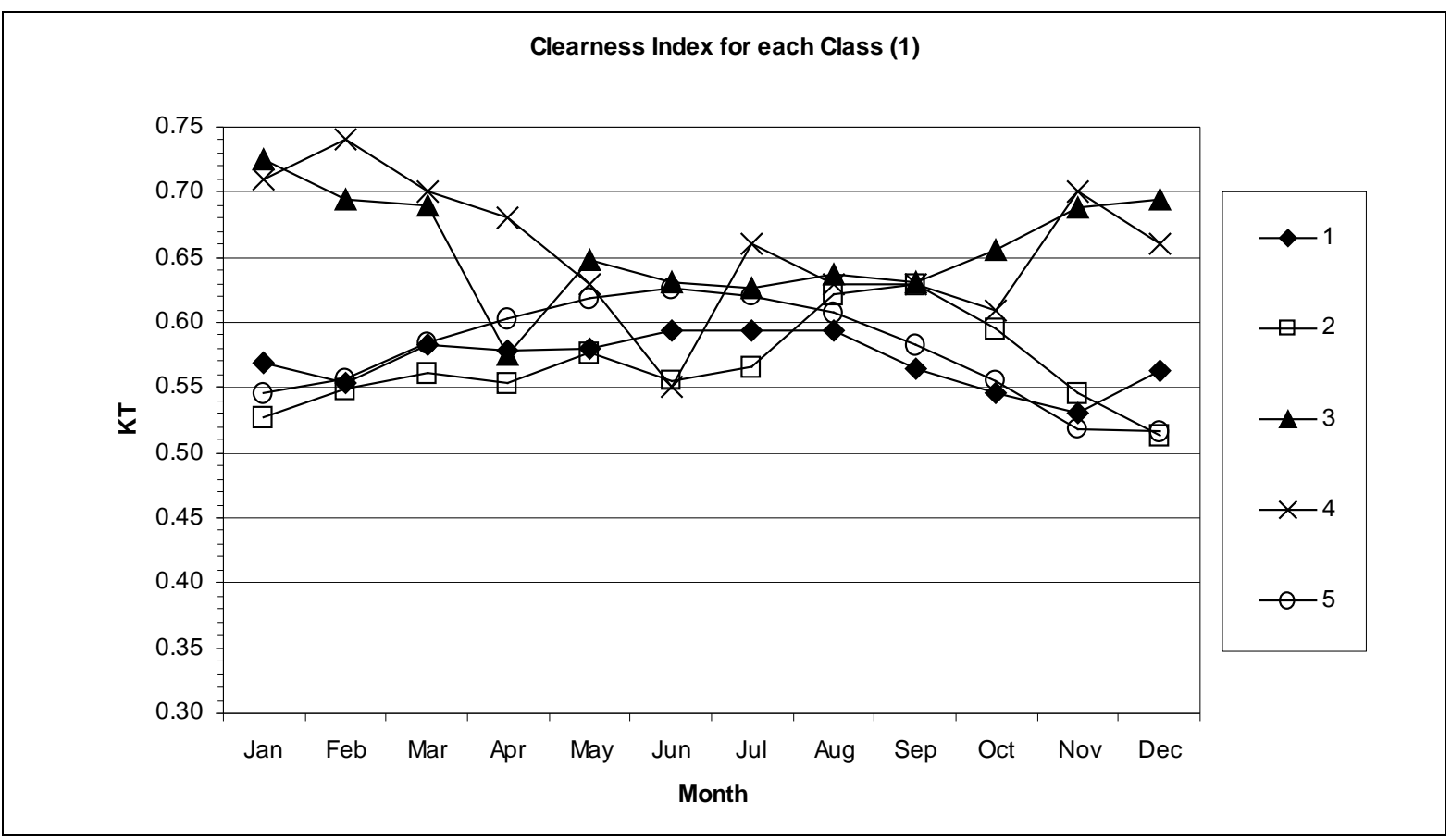

Figure 4. The annual variation of the class-averaged $\left(K T_{\mathrm{d}}\right)_{\mathrm{m}}$ for a class. Classes 1 to 5

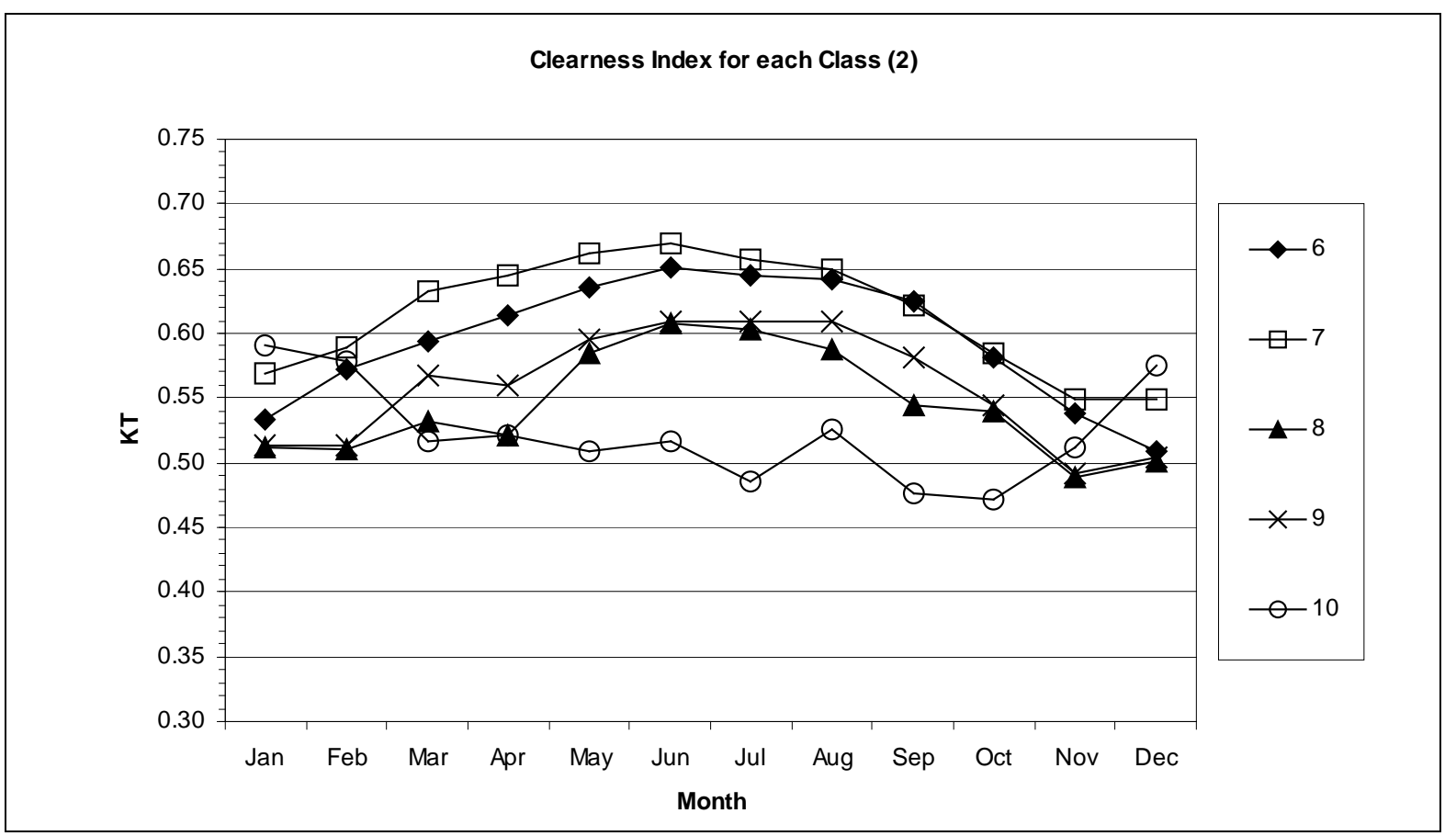

Figure 5. As Fig. 4. Classes 6 to 10 
Clearness Index for each Class (3)

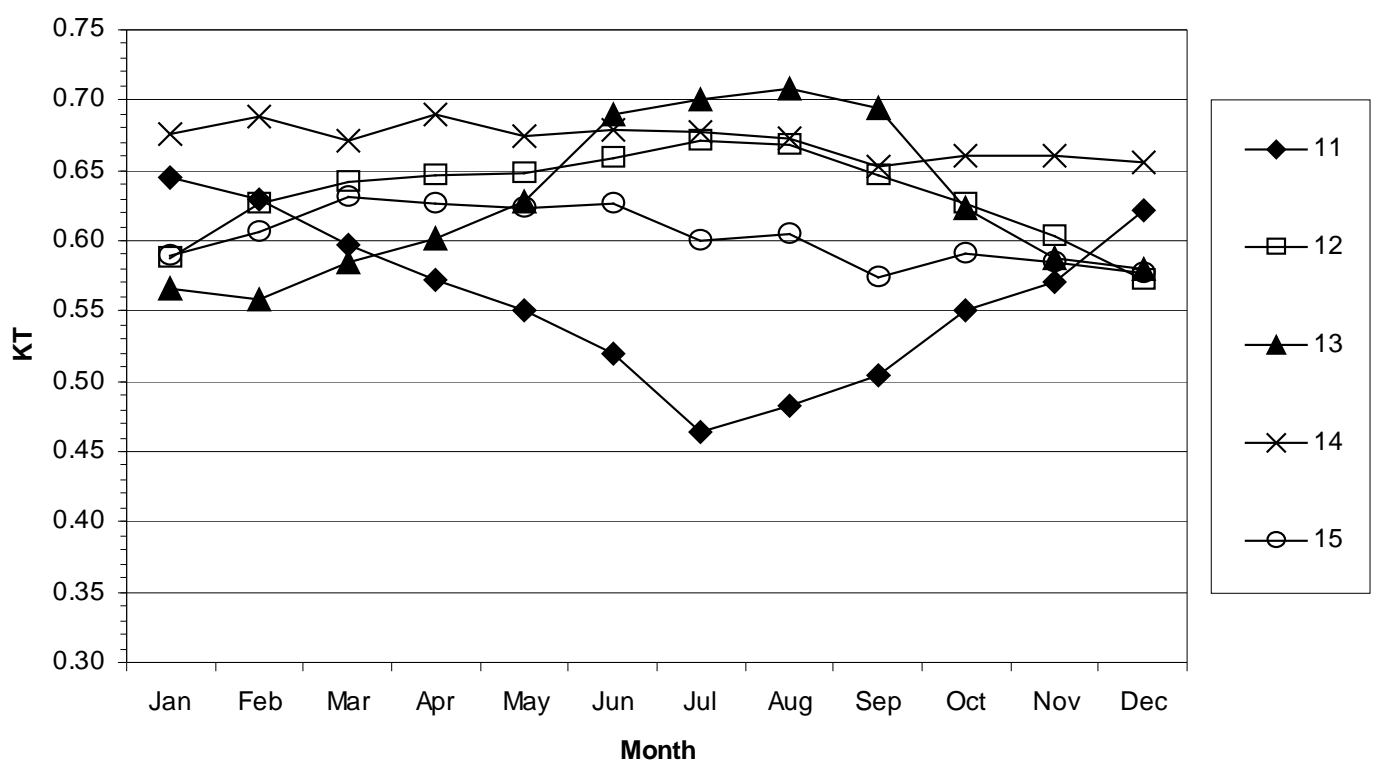

Figure 6. As Fig. 4. Classes 11 to 15

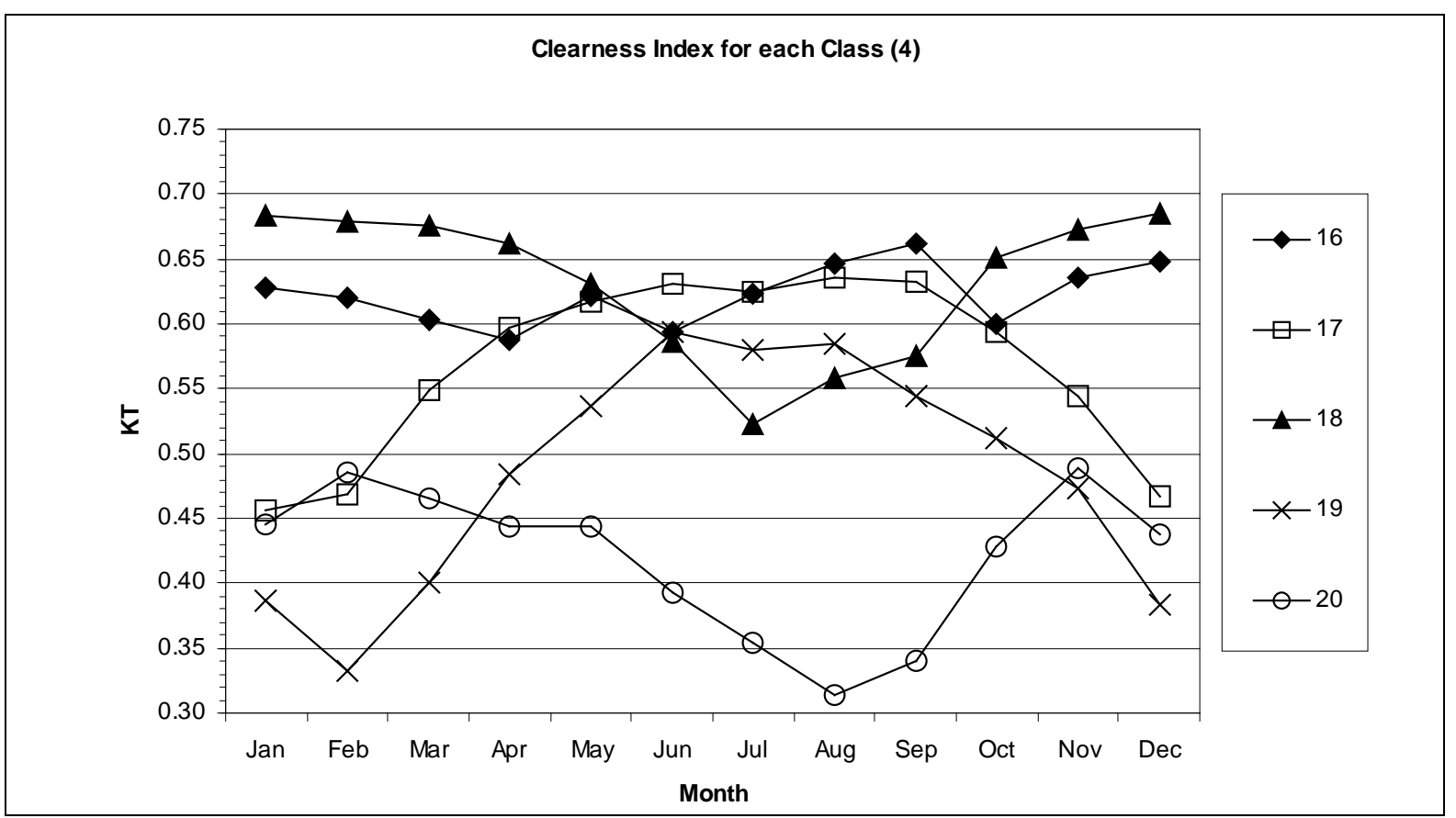

Figure 7. As Fig. 4. Classes 15 to 20 